\title{
The United States of America's interlocked information industry: An examination into seven U.S. media sectors' boards of directors
}

Jennifer L. Harker

West Virginia University, jennifer.harker@mail.wvu.edu

Follow this and additional works at: https://researchrepository.wvu.edu/faculty_publications

Part of the Journalism Studies Commons, Mass Communication Commons, Other Sociology Commons, Public Relations and Advertising Commons, Quantitative, Qualitative, Comparative, and Historical Methodologies Commons, and the Work, Economy and Organizations Commons

\section{Digital Commons Citation}

Harker, Jennifer L., "The United States of America's interlocked information industry: An examination into seven U.S. media sectors' boards of directors" (2020). Faculty \& Staff Scholarship. 1250.

https://researchrepository.wvu.edu/faculty_publications/1250

This Article is brought to you for free and open access by The Research Repository @ WVU. It has been accepted for inclusion in Faculty \& Staff Scholarship by an authorized administrator of The Research Repository @ WVU. For more information, please contact beau.smith@mail.wvu.edu. 


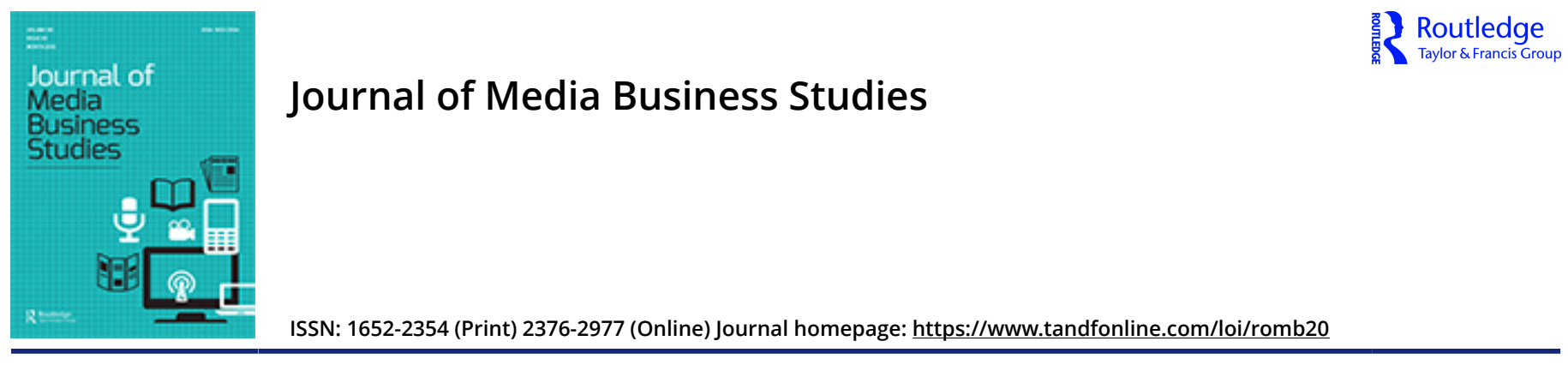

\section{The United States of America's interlocked information industry: An examination into seven U.S. media sectors' boards of directors}

Jennifer L. Harker

To cite this article: Jennifer L. Harker (2020): The United States of America's interlocked information industry: An examination into seven U.S. media sectors' boards of directors, Journal of Media Business Studies

To link to this article: https://doi.org/10.1080/16522354.2020.1726671

曲 Published online: 29 Feb 2020.

Submit your article to this journal $₫$

Q View related articles ¿

View Crossmark data $₫$

Full Terms \& Conditions of access and use can be found at https://www.tandfonline.com/action/journallnformation?journalCode=romb20 


\title{
The United States of America's interlocked information industry: An examination into seven U.S. media sectors' boards of directors
}

\author{
Jennifer L. Harker (iD) \\ Reed College of Media, West Virginia University, Morgantown, WV, USA
}

\begin{abstract}
This research explores the interfirm interlock networks that currently exist among publicly traded media conglomerates operating in the United States of America. Directorship information was gathered from annual reports and definitive proxy reports filed with the U.S. Securities and Exchange Commission for 68 media conglomerates across seven media sectors for year ending 2018. This investigation applies social resource theory to assess the social networks formed by interfirm interlocks among media conglomerates and how such network structures address environmental uncertainty. Results indicate that not all alliances are mutually beneficial and those that are more resource-dependent endure negative cooptation effects. Moreover, today's financial interlocks look very different than they did at the turn of the century. This research discusses how these changes in interfirm interlocks have resulted in directorship wars. Practical implications are discussed.
\end{abstract}

\section{ARTICLE HISTORY}

Received 14 September 2019 Accepted 4 February 2020

\section{KEYWORDS}

Media conglomerates; social network analysis; interfirm interlocks; social resource theory

Directorship wars are being waged within media conglomerates in the United States of America (U.S./American). Media conglomerates operating in the U.S. are pressured by majority shareholders to place preferential individuals on media conglomerates' boards of directors. In early 2019, a battle occurred between Gannett and its majority stakeholder, MNG [MediaNews Group] Enterprises, Inc., which is a subsidiary of Alden Global Capital. MNG, also known as Digital First Media (MNG Enterprises, Inc., 2019), submitted at least 25 proxy statements to Gannett's stakeholders via the U.S. Securities and Exchange Commission (SEC) to push its agenda for three named directors to be placed on Gannett's board. Gannett pushed back, and according to the vote tally from the annual shareholders meeting held on 17 May 2019, Gannett won that battle and all three of its current directors retained their seats (Gannett Investor Relations, 2019; O'Connell, 2019). Since, Gannett merged with New Media Investment Group and only three of Gannett's nine directors were allowed to continue to serve on the newly-merged board.

Newspaper organisations are not the only media conglomerates being pressured for board seats. MDC Partners Inc., which owns and operates numerous advertising and public relations agencies, settled a legal matter with its majority shareholder, hedge fund

CONTACT Jennifer L. Harker $\otimes$ jennifer.harker@mail.wvu.edu; @jennifer_harker @ Reed College of Media, West Virginia University, P.O. Box 6010, Morgantown, WV 26506, USA

(c) 2020 Media Management and Transformation Centre 
FrontFour Capital Group LLC in April 2019 regarding MDC's board (MDC, 2019; Thomas, 2019). Part of that agreement was the placement of Kristen O'Hara to MDC's board and the co-vetting of a second future director. The hedge fund was seeking three seats on MDC's board.

The television and radio broadcast, and motion picture sectors also forming new boards and restructuring others as a result of recent mergers and bankruptcies. For example, twenty-first Century Fox merged with The Walt Disney Company and the newly separated Fox Corporation, the parent of Fox News, has added former U.S. Speaker of the House, Republican Paul Ryan to its board of directors (Stelter, 2019). Radio conglomerate iHeartMedia filed Chapter 11 bankruptcy and reported in November 2018 its "post-emergence board" (iHeartMedia, 2018).

So, what does all this mean exactly? It means that publicly traded media conglomerates experience the same boardroom brawls as other industries, but research on these matters in the media industry is sparse, and for some media sectors, nonexistent (An \& Jin, 2004; Han, 1988; Picard, 2006, 1994; Simmons, 2012, 2011). Board governance is a critical aspect to monitor regarding media organisations because the media's political and social influence remains "critical to human society" (Artero, 2009, p. 23). Governance is expected of shareholders and the role of that governance is to influence management (Picard, 2005a). In media organisations, will such governance continue to support the civic watchdog duties of journalism? Or will such governance eventually give way to agenda-cutting due to the economic, political, or social pressures that trickle down to newsrooms (Colistra, 2018, 2012)? Are the directorship wars the tell-tale signs that the days of strategic selection of board members are coming to an end for media conglomerates? The current research examines today's directorships across seven media sectors: advertising, cable, motion picture/video production, newspaper, radio, and television to explore these questions.

This study applies a network perspective as both the theoretical and methodological approach to examine interlocks among media conglomerates in the U.S. Past approaches to studying the phenomenon of board interlocks have included network analyses (Beckman, Haunschild, \& Phillips, 2004; Koenig \& Gogel, 1981; Lamb \& Roundy, 2016; Palmer, Friedland, \& Singh, 1986; Xia, Wang, Lin, Yang, \& Li, 2018), but none such network studies have focused on board interlocks across U.S. media sectors (Picard, 2006). The current research addresses this gap in the interlocking, media studies and the network literatures.

\section{Literature review}

A board directorship provides corporate governance and oversight for publicly traded organisations (Artero, 2009). Directors are recruited for their power, prestige, and prowess and these individuals are asked to serve on the board of directors because of what they can bring to or offer the organisation through resources, expertise, or reputation (Lamb \& Roundy, 2016; Mizruchi, 1996; Schoorman, Bazerman, \& Atkin, 1981; Zajac \& Westphal, 1996). In the media sector, corporate governance is often handled by the board of directors (Artero, 2009). A conglomerate's chief executive officer (CEO) serves as board president (Mizruchi, 1996; Zajac \& Westphal, 1996) and the CEO and directors govern the highest level of operations to provide oversight regarding legal, financial, political, social, and personnel matters (An \& Jin, 2005, 2004; Artero, 2009; Han, 1988; Mizruchi, 1996; Mizruchi \& Stearns, 1988; Palmer et al., 1986; Simmons, 2012). Directors are recruited to 
serve on media conglomerate boards for their expertise in the industry, perceived prestige in the media industry, or because that person is well connected to resources of interest for the media organisation (Lamb \& Roundy, 2016; Mizruchi, 1996; Schoorman et al., 1981; Zajac \& Westphal, 1996).

When a director agrees to serve on a board, that director forms an interfirm interlock between two or more organisations; their own business(es) and that of the board on which they serve (Mizruchi, 1996). When a person affiliated with one business or "firm," sits on the board of directors of another, an "interlocking" of the two firms create a networked interfirm tie (Mizruchi, 1996, p. 271). Interfirm interlocks create connections between organisations and influential individuals for mutual benefit (Lamb \& Roundy, 2016). These benefits range from personal to organisational. At the personal level, benefits include career advancement and social cohesion (Mizruchi, 1996; Mizruchi \& Stearns, 1988). Serving on a board expands the directors' social network, advances career opportunities, and can be mutually beneficial for the directors' firm(s) as well. At the organisational level, interlocks are sought by organisations for resource exchange (financial or other critical resources), monitoring, signalling, and for reputation or image transfer in the building up of human capital for perceived organisational legitimacy (Lamb \& Roundy, 2016). Other resultant benefits from interlocks include access to diverse or unique information, shaping perceptions of the organisation, improving organisational performance, resource exchange; and the diffusion of strategies, practices and ideas-all in the quest for reduction of environmental uncertainty. This research, therefore, explores the individual, organisational, and sector-level challenges and benefits of interlocks within media conglomerates operating in the U.S.

\section{Environmental uncertainty leads to resource dependency}

Environmental uncertainty, such as economic instability or rapid technological change, leads organisations to form alliances (Beckman et al., 2004; Xia et al., 2018). Alliances are formed with individuals and organisations that can link the media conglomerate to the resources needed to weather the storms of uncertainty (Lamb \& Roundy, 2016; Lang \& Lockhart, 1990; Schoorman et al., 1981; Simmons, 2012). For example, economic instability leads organisations to increase interlocks with financial institutions (Mizruchi \& Stearns, 1988).

Environmental uncertainty is experienced at both the organisational level as well as at the industry or sector level (Beckman et al., 2004; Mizruchi \& Stearns, 1988). An example of sector-level uncertainty occurred when the whole newspaper sector experienced a shift to digital subscriptions, and thus print advertising income decreased (Mirer \& Harker, 2019). Or at the organisational level, when a newspaper conglomerate experienced environmental uncertainty if it was slow to adopt digital subscriptions as paper subscriptions began to fade.

Resources can become scarcer when sector-level uncertainty occurs. The more constrained a sector, the more niche the interlocks sought with prestigious individuals and organisations that can help reduce that uncertainty (Galaskiewicz, Wasserman, Rauschenbach, Bielefeld, \& Mullaney, 1985; Lang \& Lockhart, 1990; Zajac \& Westphal, 1996). Alternatively, Beckman et al. (2004) noted that organisational-level uncertainty causes organisations to "exploit and reinforce their networks" by "adding additional interlock and alliance relationships” (p. 272). In other words, when sector-level uncertainty is absent, organisations can seek broader or more diverse interlocks. 


\section{Functional and specific alliances}

The establishment of specific beneficial alliances were best explained by Weiss (1974) in the early discussions regarding functional specificity. Functional specificity hypothesises that organisations activate ties with certain other individuals, organisations, and industry sectors for access to necessary resources (Perry \& Pescosolido, 2010; Weiss, 1974; Wellman \& Wortley, 1990). These functional and specific alliances create interfirm interlocks that aid in meeting needs during times of uncertainty by "stabilizing the resource flow" and by strengthening "social power by affiliating with other important players" (Xia et al., 2018, p. 1900). Functional specificity, therefore, connects individuals and organisations in purposeful ways to best address resource dependency.

\section{Resource dependency}

Resource dependency is defined as a reliance on outside sources to meet operational needs. Resource dependency is driven by those functional and specific strategies mentioned above in an effort to obtain the resources necessary for daily business functions. Resource dependency is often rooted in perception (Wry, Cobb, \& Aldrich, 2013) and possesses "power imbalances" (Zona, Gomez-Mejia, \& Withers, 2018, p. 591). The power imbalances, depending on how much the resource is needed, can become so dependent that interlocks can lead to overwhelming interdependence that results in interlocks that infiltrate organisational operations and leaves organisations vulnerable and over-dependent (Lang \& Lockhart, 1990; Mizruchi \& Stearns, 1988).

Board interlocks that form in response to resource dependency have been researched by economists and sociologists for decades because board interlocks are in direct relation to, and an assumed remedy for environmental uncertainty (Lamb \& Roundy, 2016; Lang \& Lockhart, 1990; Schoorman et al., 1981; Simmons, 2012). Board interlocks aid resource dependency (Xia et al., 2018; Zona et al., 2018) through cooptation (Mizruchi, 1996; Mizruchi \& Stearns, 1988). Cooptation "involves surrendering a certain amount of autonomy in return for access to resources" (Mizruchi \& Stearns, 1988, p. 195). An example of cooptation of directors for resource exchange would be a board member who is a bank executive or a venture capitalist that offers access to financial resources. Therefore, it is these linkages established between organisations and outside individuals and their organisations, that best address resource dependency, but can come at a high price.

Resource dependency also stretches across horizontal and vertical exchanges (Pfeffer \& Salancik, 2003; Xia et al., 2018; Zona et al., 2018), meaning that functional specificity will cause an individual or organisation to seek out peers (horizontal) or industry leaders (vertical) for resources. There are four ways in which interlocks have assumed benefit regarding resource dependency: horizontal coordination linking competitors; vertical coordination linking an organisation with suppliers of inputs or receivers of outputs; expertise; and by enhanced reputation (Schoorman et al., 1981, p. 243). What this means is when environmental uncertainty is occurring, organisations might exchange resources horizontally with similar or competitor organisations, or an organisation might seek out alliances with organisations vertically superior or inferior. Expertise and reputation links back to prestige being a key indicator for director selection (Galaskiewicz et al., 1985).

In sum, environmental uncertainty leads to resource dependency. Interfirm interlocks aid in accessing necessary resources during times of uncertainty. Such an exchange of 
resources among these functional and specific alliances that form can become critical to the wellbeing of organisations. As such, the first research question is posited:

RQ1: How are today's U.S. media conglomerates addressing resource dependency through board interlocks?

The next section explains how and why board interlocks have formed among media organisations in the U.S. over the past four decades (Picard, 2006) and how such alliances address resource dependency.

\section{Board interlocks among media conglomerates in the U.S}

According to Picard (2006), media economics researchers explore how media organisations behave, communicate, and operate in response to financial and societal structures. Corporate governance across media sectors can be challenging to harness and assess. This is because of the media industry experiences similar financial and managerial challenges and opportunities as other industries, but because of the diverse variance of media products, each media sector can vary widely in best practices and in operations (Picard, 2005b). Still though, several ongoing risks stretch across all media sectors creating environmental uncertainty and thus resource dependency. The risks to operations and economic viability of the media industry include technology shifts, the evolution of financial markets and global economies, the impact of corporate acquisitions, competition, legal considerations and labour disputes, just to name a few (Artero, 2009, pp. 133-134; Picard, 2003).

Media and technology have followed along a nonlinear evolutionary process creating numerous "infrastructures and institutions in the past century" that now include media sectors spanning newspapers, telephony, movies, radio, television, satellite-based cable television, and advertising and public relations agencies (Logan, 2007; Neuman, 2010, p. 1; Scolari, 2013). Further, each of these sectors uniquely navigate the digital and technological advancements brought on by the twenty-first century's implementation of the internet. Such technological dynamism, which is the process of technological change that affects organisations both internally and externally (Tatarynowicz, Sytch, \& Gulati, 2016), alongside growing environmental uncertainty for some media sectors, couple to reshape the composition of media conglomerates' leadership and governance structures.

Three multi-sector studies have explored these structures. Han (1988) conducted research on board interlocks among media conglomerates in the U.S. by examining the leading 50 publicly traded media firms of the time to investigate resource dependency upon advertising, financial constraints, and market diversification in relation to board interlocks. Han's approach was to examine the directors representative of advertisers, financial institutions, law firms, and competitors. The average number of directors in the 1980s was 11.94, and in order of frequencies, those most common interlocked directors hailed from the financial, advertiser, law, and competitor sectors. Han's work paved the way for subsequent examinations.

In the time that passed between Han's research on 50 publicly traded media conglomerates in 1987 to An's and Jin's research in the early 2000s, media conglomerates had already begun to consume the smaller organisations. An and Jin (2004) therefore reviewed whether financial dependency of the remaining 13 publicly traded newspaper publishing conglomerates resulted in interlocks reflective of that dependency. The gap in 
time from Han's (1988) research was accounted for by the authors by conducting a longitudinal study spanning the years 1988 to 2000. Results indicated that conglomerates with higher financial dependency were more likely to interlock with capital resources. This result was further compounded when internal sources of financial support decreased. The larger media conglomerates in this study ranged in financial interlocks from $45 \%$ to $60 \%$ of the board's structure but overall between $13 \%$ and $57 \%$; and advertising directors ranged from zero to $31 \%$. An \& Jin's hypotheses, that stated environmental uncertainty and resource dependency would result in an increase of financial and advertiser director interlocks, were only partially supported.

Finally, the third interlocking study conducted within the media industry spanned from 1990 to 2009 and reviewed 17 publicly traded media conglomerates (Simmons, 2012). Simmons' research stretched across five media sectors to include newspaper, radio, television, movie production, and digital media outlets. Simmons, who also researched the legal considerations regarding media interlocks (2011), investigated the changes the media industry had faced during that time period as the industry shifted to digital platforms. Key findings noted that media conglomerates responded more to economic instability than to technological change, or technological dynamism (Tatarynowicz et al., 2016). Therefore, media conglomerates that experienced the highest levels of environmental uncertainty recruited directors from financial institutions and advertisers.

Taken together, environmental uncertainty leads organisations to seek out functionally specific alliances in an effort to connect to the necessary resources that organisations depend upon for survival. Functional, specific-interlocked directorates help to reduce environmental uncertainty and aids technological change through these strategic alliances (Beckman et al., 2004; Tatarynowicz et al., 2016). Considering these matters, the following hypothesis is presented:

H1:Although today's U.S. media conglomerates across the seven sectors have differed regarding adaption to technological change, interfirm interlocks with digital or technological organisations will be present across all media sectors.

The research to this point has explained that resource dependency is determined by environmental uncertainty (Xia et al., 2018). This research argues that by examining media interlocks through a network perspective, a more precise view into the strategic nature of media interlocks may be revealed. The next section provides an overview of this approach to position the theoretical argument and the methodological approach.

\section{Applying the network perspective to today's U.S. media board interlocks}

The network perspective is a descriptive examination of sociological connections. Networks are made up of nodes and ties, and each can be operationalised in virtually non-exhaustive ways, as long as the node is an entity or actor that connects (or ties) to other nodes in a network of some specified manner (Borgatti, Everett, \& Johnson, 2013; Borgatti \& Lopez-Kidwell, 2011). A node in this research is operationalised as a media conglomerate and its ties to the directors (and each directors' organisation) serving on the media conglomerate's board, (Palmer et al., 1986).

The network perspective examines how nodes are interconnected (network architecture) and the opportunities that exist among those connections for an exchange of 
resources (network flow). The flow of resources through networked individuals and organisations is best defined by Lin's $(2017,1999$ a) social resource theory. Social resource theory is rooted in the foundational perspectives of social capital (Bourdieu, 1985) and connects to Coleman's (1988) work regarding the benefits of human capital. Social resource theory suggests that social embeddedness, and therefore access to resources, can best address environmental uncertainty (Burt, 2004; Granovetter, 1973).

Lin (1999b) asserted that social resources are "accessible through one's direct and indirect ties" (p. 467). Lin's application of network theory to the concept of social capital resulted in the formulation of three propositions: (1) that social resources are accessed in social networks to exert a specified outcome; (2) the strength of position where desired social resources are located in the network; and (3) the strength of ties to social resources and whether activation is vertical or horizontal in nature (p. 470). Social resource theory thus connects to the interlocking literature because it is well established that organisations form alliances to reduce environmental uncertainties such as economic instability (Beckman et al., 2004) and technological change (Tatarynowicz et al., 2016). The organisations "with power from a central network position" are best positioned to survive uncertainty, instability, and withstand change because they are better positioned for resource exchange (Xia et al., 2018, p. 1916).

This underlying premise to social resource theory that individuals, or organisations through its individuals' connections, access, and mobilise resources embedded within their social networks results in increased human capital and a higher exchange of social resources (Burt, 2004; Coleman, 1988; Nahapiet \& Ghoshal, 1998), makes social resource theory the appropriate theoretical framework with which to examine board interlocks. This is especially true given that interlocking research stretches across levels of measurement from a micro or individual level to organisational and industry or sector levels of measurement. The micro-level data typically collected in directorship investigations possesses implications at the meso or macro levels (Koenig \& Gogel, 1981). Network statistics allows for such a multi-level, whole-view examination of the individual-toorganisation and the organisation-to-industry levels of analysis (Xia et al., 2018).

Taken together, social resource theory's descriptive, multi-level network structure can identify the "compositional quality" of interconnected media conglomerates and whether or in what ways media conglomerates' needs are being met by board interlocks (Borgatti, Jones, \& Everett, 1998, p. 30; Lin, 2017). As such, this research examines the social network architecture and flow of resource dependency and exchange among interlocked individuals and organisations across seven sectors of the U.S. media industry. The resource dependency and exchange cluster of network theories are applied to provide a multi-level framework for the assessment of the current sociological networks created by the publicly traded media conglomerates operating in the United States of America (Monge \& Contractor, 2003).

This research, therefore, sets out to build upon past media economic studies (An \& Jin, 2005, 2004; Artero, 2009; Han, 1988; Picard, 2006, 2005a; Simmons, 2012, 2011) and posits the following additional research question and hypothesis regarding the investigation of media conglomerates' board interlocks from a network perspective through the lens of social resource theory: 
RQ2: What can the network architecture and flow of today's U.S. media conglomerates' board interlocks explain and what do these structures suggest regarding resource exchange and dependency across the individual, organizational and sector levels?

Researchers have warned that interlocks can result in infiltration and organisations should remain cautious of relying on high levels of interdependence. Taking this into consideration, how might social resource theory be demonstrated throughout the whole network of U.S. media sectors? This research hypothesises the following:

H2: The advertising sector holds a central position within the U.S. media conglomerates' network.

The next section provides a detailed account regarding the specific methods and measurements applied to address the research questions and hypotheses guiding this research. The method section begins with an explanation of the network measurements applied and then details the data gathering and data analysis approach.

\section{Method}

It is important to note that there are two approaches to researching networks: whole networks or ego networks (Borgatti et al., 2013; Borgatti \& Lopez-Kidwell, 2011; Perry, Pescosolido, \& Borgatti, 2018). A whole network encompasses all possible connections within a specified boundary. Alternatively, an ego network examines one entity's (an ego) connections (Borgatti et al., 2013). Coleman (1988) argued that an ego's connections become that ego's human capital because those connections work together to help the ego acquire or exchange resources. Arguably, each media conglomerate possesses its own ego network; however, this research takes a sociological stance regarding U.S. media and examines the sociological phenomena of the dependency and exchange network theories at play across the seven sectors. Therefore, ego networks would be too micro to examine alone. So, a whole network analysis was included to this investigation, as is supported by researchers who assert that interfirm interlocks explored through network structures require the whole network approach (Walker, Kogut, \& Shan, 1997).

\section{Data identification}

A census of U.S. media-related conglomerates was collected. This data gathering process was conducted using online business and governmental databases and search engines to locate publicly available information. First, all businesses in the United States of America registered to operate under the various Information Services categorisation (cf. Xia et al., 2018) were gathered through identification and registration under the North American Industry Classification System (NAICS). The NAICS code system is a federal system used to classify all U.S. industries into 20 categories. The NAICS codes were established in 1997 to replace the Standard Industrial Classification (SIC) $\operatorname{code}^{1}$ (United States Census Bureau, 2017). The categorisations under the "Information" industry include newspaper publishers, radio and television broadcasting, news syndicates, and internet publishing. For example, the NAICS code for newspaper publishers begins with 51111, radio and television broadcasting 51511, news syndicates 51911, and Internet publishing is 51913. Extending this investigation, numerous other mass communication conglomerates not investigated in prior media studies were 
included: advertising and public relations agencies and advertising services (54181, 541812), and digital advertising [independent representatives primarily engaged in selling media time or space for media owners specifically online] (54184, 54187, 541813) conglomerates were collected. Further, cable and other subscription programming (51521), and the motion picture and video production (51211) also were included in this investigation. See Table 1 for a full list of conglomerate organisations.

Data regarding all public and private U.S. media-related conglomerates operating in the U.S. under an NAICS code were gathered using the Mergent Intellect online database. The database is available through the primary investigator's university library services. First, each industry sector's code was entered into the industry search capability and all data regarding each conglomerate listed under that industry categorisation were downloaded into excel spreadsheets. The Mergent Intellect online database is connected to D-U-N-S identification system through Dun \& Bradstreet which "continually verifies records using a wide variety of sources." Mergent Intellect also displays the date when the last edit was made to each organisation's available information. The oldest record within this initial dataset was dated February 2017 and the majority of records were updated during spring 2018. The excel spreadsheets of all conglomerates classified as specified in the paragraphs above were downloaded and saved. Each publicly traded media conglomerate was identified in those datasets. The non-publicly traded organisations were eliminated from this interlocking investigation because information regarding boards of directors are not consistently available, if boards exist at all (cf: Beckman et al., 2004).

\section{Data collection}

The directors for each of the publicly traded media conglomerates were then collected. Directors were identified and verified in a two-step process. Directors were identified by pulling each conglomerate's 10-K annual report and DEF 14 definitive proxy reports from the EDGAR database available at the SEC website [sec.gov]. This process, informed by past research, also helped to verify the conglomerates still operating and this process was effective in the collection of the most updated directorship information (Beckman et al., 2004; Han, 1988; Simmons, 2011). The 10-K annual reports and definitive proxy report filings by the conglomerates list all directors and were filed after the calendar year 2018 concluded. The majority of the annual reports were filed Feb. 2019. When no recent SEC filings for 2018 or 2019 were recorded in the EDGAR database or when the conglomerate was flagged as terminated or acquired, that media conglomerate was removed from the study because the absence of SEC filings was deemed a verification of discontinued business operations. All DEF 14 proxy reports were collected for each conglomerate still in operation. The proxy reports list all current directors and include director biographies with their most recent employment, as well as executive compensation in the "summary compensation table" and director compensation in the "director compensation table." Each conglomerates' board president (often the CEO) and directors' compensation data were collected from these official reports (Beckman et al., 2004; Simmons, 2012: Zajac \& Westphal, 1996). Finally, each director's most recent place of employment was collected from the proxy reports to examine the interfirm interlocks present among these media conglomerates.

Once all directorship information was collected for the media conglomerates across the seven media sectors [advertising, cable, digital advertising, motion picture and video production, newspaper, radio, and television], each directors' most recent employer was then categorised using the NAICS code alongside an online search to verify the director's connection to 
the reported most recent employer. Executives who sat on their own boards were fully recorded but were not included in the current employer categorisation (cf: Mizruchi, 1996).

Then, another layer of categorisation of those NAICS codes was conducted mirroring Simmons (2012) prior research, which used the following broad interfirm interlock resource categories: Media, which included newspaper, motion picture, radio, broadcast and cable television, and publishing; Digital-Technology, which include computer, cybersecurity, software, electronics, telecommunication, internet, artificial intelligence, virtual reality, and bitcoin; Financial, included banking, accounting, insurance, venture capital, investment firms, brokerage or holding companies, real estate, and business management and consultancies (cf. Mizruchi \& Stearns, 1988). Advertisers, included manufacturers, retailers, sports teams and clubs, travel agencies, celebrity agents or entertainment promoters, chain restaurants, large health-care systems, and pharma; Law, included law firms and lawyers. One category was extended to catch the Government/Nonprofit/Education organisations left over from the other resource categories. The Government/Nonprofit/Education category included educational institutions, trade associations, governmental agencies or politicians, public utility companies, and civic and social organisations (Beckman et al., 2004).

Social network analysis centrality measurements were analysed using NodeXL Pro Version 1.0.1.413 (Smith et al., 2010). Illustrations of the social networks, or sociograms, which offer a visual representation of a network and aids the researcher in examining the architecture of a network (Scott, 1988), were constructed using NodeXL Pro. Centrality measurements, which assess a node's access to resources throughout its network, were calculated to explore how many connections a node has (i.e. degree centrality), how many other nodes must be passed through to reach destinations within the network (i.e. betweenness centrality), and how many connections a node's connections have (i.e. eigenvector centrality) to assess the full reach of nodes throughout the network (Opsahl, Agneessens, \& Skvoretz, 2010).

\section{Results}

The first research question asked how today's U.S. media conglomerates' board interlocks might address resource dependency. To explore this question, media conglomerates were gathered across seven media sectors: advertising $(\mathrm{n}=15)$, cable $(\mathrm{n}=10)$, digital advertising $(\mathrm{n}=4)$, motion picture and video production $(n=2)$, newspaper $(n=12)$, radio $(n=13)$, and television $(n=12)$.

The method described above resulted in the collection of all members of the boards of directors $(\mathrm{N}=602$, [ $\mathrm{n}=582$ unique directors; 28 duplicates $])$ for each of the publicly traded media conglomerates $(n=68)$ in the U.S. Executives who sat on their own boards $(\mathrm{n}=122)$ were recorded and these instances are notated as "Org" in the interfirm interlock resource categories. There were 412 unique interfirm interlocks (i.e. directors' most recent or current employer). The resource categories representative of the directors' organisations included media $(n=117)$, digital-technology $(n=48)$, financial $(n=182)$, advertisers $(n=77)$, law $(n=18)$, and government/nonprofit/education $(n=45)$.

Directorships ranged from 3 to 16 directors. The largest directorships included AMC Networks Inc $(\mathrm{n}=16)$, The Walt Disney Company $(\mathrm{n}=16)$, The New York Times Company $(\mathrm{n}=14)$, Berkshire Hathaway Inc $(\mathrm{n}=14)$, MSG Networks Inc $(\mathrm{n}=13)$, and Sirius XM Holdings Inc $(n=13)$. The average compensation across all directors was $\$ 1,387,752$, but this includes annual compensation of executives who served on their own 
Table 1. Publiclytraded media conglomerates across seven media sectors in the U.S.

\begin{tabular}{|c|c|c|}
\hline Media Conglomerate & Media Sector & $\begin{array}{c}\text { Number of } \\
\text { Directors }\end{array}$ \\
\hline 1. A. H. BELO CORPORATION & Newspaper & 8 \\
\hline 2. AMC NETWORKS INC & Television & 16 \\
\hline 3. ANGI HOMESERVICES INC & Advertising & 11 \\
\hline 4. BEASLEY BROADCAST GROUP INC & Radio & 9 \\
\hline 5. BERKSHIRE HATHAWAY INC & Newspaper & 14 \\
\hline 6. CABLE ONE INC & Cable & 8 \\
\hline 7. CBS CORPORATION & Television & 12 \\
\hline 8. CHARTER COMMUNICATIONS INC & Cable & 13 \\
\hline 9. COMCAST CORPORATION & Television & 13 \\
\hline 10. CUMULUS MEDIA INC & Radio & 7 \\
\hline 11. DAILY JOURNAL CORPORATION & Newspaper & 5 \\
\hline 12. DIGITAL BRAND MEDIA \& MARKETING GROUP INC & Advertising & 3 \\
\hline 13. DISCOVERY INC & Cable & 12 \\
\hline 14. DISH NETWORK CORPORATION & Cable & 10 \\
\hline 15. E.W. SCRIPPS COMPANY & Television & 9 \\
\hline 16. EMMIS COMMUNICATIONS CORP & Radio & 9 \\
\hline 17. ENTERCOM COMMUNICATIONS CORP & Radio & 9 \\
\hline 18. ENTRAVISION COMMUNICATIONS CORPORATION & Television & 7 \\
\hline 19. GANNETT CO INC & Newspaper & 10 \\
\hline 20. GRAHAM HOLDINGS COMPANY & Newspaper & 10 \\
\hline 21. GRAY TELEVISION INC & Television & 11 \\
\hline 22. GROUPON INC. & Advertising & 9 \\
\hline 23. HEMISPHERE MEDIA GROUP INC & Cable & 10 \\
\hline 24. IHEARTMEDIA INC & Radio & 13 \\
\hline 25. INTERPUBLIC GROUP OF COMPANIES INC & Advertising & 11 \\
\hline 26. IZEA WORLDWIDE INC & Advertising & 8 \\
\hline 27. LEAF GROUP LTD & Digital Advertising & 9 \\
\hline 28. LEE ENTERPRISES INCORPORATED & Newspaper & 9 \\
\hline 29. LIBERATED SYNDICATION INC & Radio & 4 \\
\hline 30. LIBERTY MEDIA CORPORATION & Cable & 9 \\
\hline 31. LIVE VENTURES INC & Digital Advertising & 5 \\
\hline 32. LIVEXLIVE MEDIA INC & Radio & 5 \\
\hline 33. MARCHEX INC & Digital Advertising & 3 \\
\hline 34. MCCLATCHY COMPANY & Newspaper & 12 \\
\hline 35. MDC PARTNERS INC & Advertising & 11 \\
\hline 36. MOBIQUITY TECHNOLOGIES INC & Advertising & 6 \\
\hline 37. MSG NETWORKS INC & Cable & 13 \\
\hline 38. NATIONAL CINEMEDIA LLC & Advertising & 9 \\
\hline 39. NETFLIX INC & Motion Picture/Video & 11 \\
\hline 40. NEW MEDIA INVESTMENT GROUP INC & Newspaper & 5 \\
\hline 41. NEW YORK TIMES COMPANY & Newspaper & 14 \\
\hline 42. NEWS CORPORATION & Newspaper & 11 \\
\hline 43. NEXSTAR MEDIA GROUP INC & Television & 9 \\
\hline 44. NTN BUZZTIME INC & Television & 6 \\
\hline 45. OMNICOM GROUP INC & Advertising & 11 \\
\hline 46. QUOTIENT TECHNOLOGY INC & Advertising & 9 \\
\hline 47. ROKU INC & Cable & 7 \\
\hline 48. ROPER TECHNOLOGIES INC & Advertising & 10 \\
\hline 49. RUBICON PROJECT INC & Advertising & 7 \\
\hline 50. SAGA COMMUNICATIONS INC & Radio & 7 \\
\hline 51. SALEM MEDIA GROUP INC & Radio & 8 \\
\hline 52. SINCLAIR BROADCAST GROUP INC & Television & 10 \\
\hline 53. SIRIUS XM HOLDINGS INC & Radio & 13 \\
\hline 54. SOCIAL REALITY INC & Advertising & 5 \\
\hline 55. SPANISH BROADCASTING SYSTEM INC & Radio & 6 \\
\hline 56. TEGNA INC & Television & 11 \\
\hline 57. TELARIA INC & Advertising & 8 \\
\hline 58. THE TRADE DESK INC & Advertising & 8 \\
\hline 59. THESTREET INC & Newspaper & 7 \\
\hline 60. TOWNSQUARE MEDIA INC & Radio & 7 \\
\hline
\end{tabular}


Table 1. (Continued).

\begin{tabular}{llc}
\hline Media Conglomerate & \multicolumn{1}{c}{ Media Sector } & $\begin{array}{c}\text { Number of } \\
\text { Directors }\end{array}$ \\
\hline 61. TRAVELZOO & Digital Advertising & 5 \\
62. TRIBUNE MEDIA COMPANY & Television & 5 \\
63. TRIBUNE PUBLISHING COMPANY & Newspaper & 6 \\
64. URBAN ONE INC & Radio & 6 \\
65. VIACOM INC & Cable & 9 \\
66. WALT DISNEY COMPANY & Television & 16 \\
67. WIDEOPENWEST INC & Cable & 9 \\
68. WORLD WRESTLING ENTERTAINMENT INC & Motion Picture/Video & 11 \\
\hline
\end{tabular}

conglomerates' boards. Director compensation by media sector ranged widely across the seven media sectors from $\$ 210,019$ to $\$ 653,755$ (see Table 2).

This research hypothesised that although today's media conglomerates across the seven sectors differed in adaption to technological change (Tatarynowicz et al., 2016), interfirm interlocks with digital or technological organisations will be present across all sectors. This hypothesis was supported. Adaption to technological change among interfirm interlocks with digital or technological organisations were present across all seven sectors (see Table 3). The digital and technological resource category among interlocked directorships ranged from $4 \%$ (cable) to $23 \%$ (motion picture and video production) across sectors.

The second research question explored the social networks of today's media conglomerates' interfirm interlocks, the architecture these networks depict, and the dependency and exchange of resources that might flow through these network structures. To address this research question, the initial ego networks collected and reported above were combined to form two whole networks: one organisation-to-individual network and one organisation-to-organisation network. The organisation-to-individual network examines the connections among the media conglomerates and the individuals who serve on those boards. The organisation-to-organisation network examines the connections among the media conglomerates and each directors' connected organisation, or put another way, the interfirm interlocks across all seven media sectors. This research was the first to include the advertising sector within an investigation of media interlocks, and in support of the second hypothesis, three advertising conglomerates were among the top 20 most central organisations in the organisation-to-organisation network: the Interpublic Group of Companies Inc, MDC Partners Inc, and Omnicom Group (see Table 4).

Table 2. Director compensation by interfirm interlock resource category.

\begin{tabular}{lcccr}
\hline & $\mathrm{n}$ & $\mathrm{M}$ & $\mathrm{SD}$ & \multicolumn{1}{c}{$\%$} \\
\hline ADVERTISERS & 71 & $\$ 244,542$ & $\$ 200,288$ & 11.6 \\
DIGITAL-TECH & 47 & $\$ 273,470$ & $\$ 527,946$ & 7.7 \\
FINANCIAL & 175 & $\$ 210,019$ & $\$ 154,208$ & 28.7 \\
GOVT/ED/NPO* & 44 & $\$ 653,755$ & $\$ 2,702,956$ & 7.2 \\
LAW & 17 & $\$ 311,118$ & $\$ 327,520$ & 2.7 \\
MEDIA $^{*}$ & 112 & $\$ 644,816$ & $\$ 3,798,085$ & 18.3 \\
ALL COMBINED & 579 & $\$ 1,387,752$ & $\$ 4,917,569$ & \\
\hline
\end{tabular}

*Outliers in these categories. These outliers are directors who were also compensated executives.

In the Government/Education/Non-Profit Organisation category: Gregory E Abel, Berkshire Hathaway Energy, public utilities [salary: $\$ 18,013,750]$.

In the Media category: Stephen B Burke, NBCUniversal, [salary: $\$ 39,959,015]$, Rupert Murdoch, Fox Corporation, [salary: $\$ 5,742,610]$. 
Table 3. Interfirm interlock resource categories by media sector.

\begin{tabular}{|c|c|c|c|c|c|}
\hline & $\mathrm{n}$ & $\%$ & & $\mathrm{n}$ & $\%$ \\
\hline ADVERTISING & 126 & & NEWSPAPERS & 111 & \\
\hline Finance & 37 & 29 & Finance & 22 & 20 \\
\hline Org & 26 & 21 & Org & 20 & 18 \\
\hline Advertisers & 25 & 20 & Govt/Ed/NPO & 20 & 18 \\
\hline Media & 18 & 14 & Media & 19 & 17 \\
\hline Digital & 14 & 11 & Advertisers & 16 & 14 \\
\hline Govt/Ed/NPO & 4 & 3 & Digital & 11 & 10 \\
\hline Law & 2 & 2 & Law & 3 & 3 \\
\hline CABLE & 100 & & RADIO & 103 & \\
\hline Finance & 34 & 34 & Finance & 36 & 35 \\
\hline Media & 32 & 32 & Org & 26 & 25 \\
\hline Org & 15 & 15 & Media & 20 & 19 \\
\hline Advertisers & 6 & 6 & Advertisers & 8 & 8 \\
\hline Law & 6 & 6 & Govt/Ed/NPO & 7 & 7 \\
\hline Digital & 4 & 4 & Digital & 5 & 5 \\
\hline Govt/Ed/NPO & 3 & 3 & Law & 1 & 1 \\
\hline DIGITAL AD & 22 & & TV & 125 & \\
\hline Finance & 8 & 36 & Finance & 42 & 34 \\
\hline Advertisers & 6 & 27 & Org & 26 & 21 \\
\hline Org & 4 & 18 & Media & 20 & 16 \\
\hline Media & 2 & 9 & Advertisers & 14 & 11 \\
\hline Digital & 1 & 5 & Govt/Ed/NPO & 9 & 7 \\
\hline Govt/Ed/NPO & 1 & 5 & Digital & 8 & 6 \\
\hline Law & 0 & 0 & Law & 6 & 5 \\
\hline MOVIE & 22 & & & & \\
\hline Media & 6 & 27 & & & \\
\hline Org & 5 & 23 & & & \\
\hline Digital & 5 & 23 & & & \\
\hline Finance & 3 & 14 & & & \\
\hline Advertisers & 2 & 9 & & & \\
\hline Govt/Ed/NPO & 1 & 4 & & & \\
\hline Law & 0 & 0 & & & \\
\hline
\end{tabular}

Table 4. Top 20 most central media conglomerates across seven media sectors.

\begin{tabular}{lcccc}
\hline Media Conglomerate & $\begin{array}{c}\text { Degree } \\
\text { Centrality }\end{array}$ & $\begin{array}{c}\text { Betweenness } \\
\text { Centrality }\end{array}$ & $\begin{array}{c}\text { Closeness } \\
\text { Centrality }\end{array}$ & $\begin{array}{c}\text { Eigenvector } \\
\text { Centrality }\end{array}$ \\
\hline AMC NETWORKS INC & 13 & 4578.91 & 0.000750 & 0.009408 \\
SIRIUS XM HOLDINGS INC & 12 & 4038.12 & 0.000749 & 0.009408 \\
NEW YORK TIMES COMPANY & 12 & 4338.05 & 0.000749 & 0.009140 \\
CHARTER COMMUNICATIONS INC & 12 & 4362.78 & 0.000749 & 0.009023 \\
CBS CORPORATION & 12 & 4606.74 & 0.000749 & 0.008861 \\
DISCOVERY INC & 11 & 3670.82 & 0.000748 & 0.009010 \\
BERKSHIRE HATHAWAY INC & 11 & 3870.94 & 0.000748 & 0.008997 \\
COMCAST CORPORATION & 11 & 3871.93 & 0.000748 & 0.008983 \\
INTERPUBLIC GROUP OF COMPANIES & 11 & 4217.61 & 0.000748 & 0.008599 \\
INC & 11 & & & \\
TEGNA INC & 11 & 4377.33 & 0.000748 & 0.008598 \\
MCCLATCHY COMPANY & 11 & 4381.33 & 0.000748 & 0.008577 \\
MDC PARTNERS INC & 10 & 3456.96 & 0.000748 & 0.008461 \\
OMNICOM GROUP INC & 10 & 3752.59 & 0.000747 & 0.008593 \\
GANNETT CO INC & 10 & 3986.93 & 0.000747 & 0.008467 \\
NETFLIX INC & 10 & 4230.00 & 0.000747 & 0.008343 \\
GREY TELEVISION INC & 10 & 4230.00 & 0.000747 & 0.008208 \\
ROPER TECHNOLOGIES INC & 9 & 2633.84 & 0.000747 & 0.008208 \\
HEMISPHERE MEDIA GROUP INC & 9 & 2514.73 & 0.000746 & 0.008968 \\
GRAHAM HOLDINGS COMPANY & 9 & 2896.87 & 0.000746 & 0.008833 \\
VIACOM INC & & & 0.000746 & 0.008720 \\
\hline
\end{tabular}

Media Sectors: Advertising $(n=4)$, Cable $(n=4)$, Motion Picture/Video Production $(n=1)$, Newspaper $(n=5)$, Radio $(n=1)$, and Television $(n=5)$. 
The organisation-to-individual network depicts the most connected directors among today's U.S. media conglomerates (see Figure 1). The top 10 most central directors include: Brian G Sweeney, Charles F Dolan, James L Dolan, Kristin A Dolan, Thomas C Dolan, William J Bell, Carl E Vogel, Jonathan F Miller, David E Van Zandt, and Frank J Biondi, Jr. The Dolan family is tied to three of the conglomerates included in this research: Altice USA Inc (Cablevision), AMC Networks Inc, and MSG Networks Inc. Carl Vogel serves on the board of three conglomerates: AMC Networks Inc, DISH Network Corporation, and Sirius XM Holdings Inc. Mr Vogel's employment organisation, Kohlberg Kravis Roberts \& Co, boasts the highest eigenvector centrality among all connected organisations, which is discussed next.

Eigenvector centrality, a network measurement of connectivity, also was calculated regarding directors' organisations. The top 10 directors' organisations most connected throughout the media conglomerates' social network include: Kohlberg Kravis Roberts \& Co, NBCUniversal, Liberty Media Corporation, Harvard University, Sony Pictures Entertainment, CBS, General Motors Company, Google, Time Warner, and Munger Tolles \& Olson.

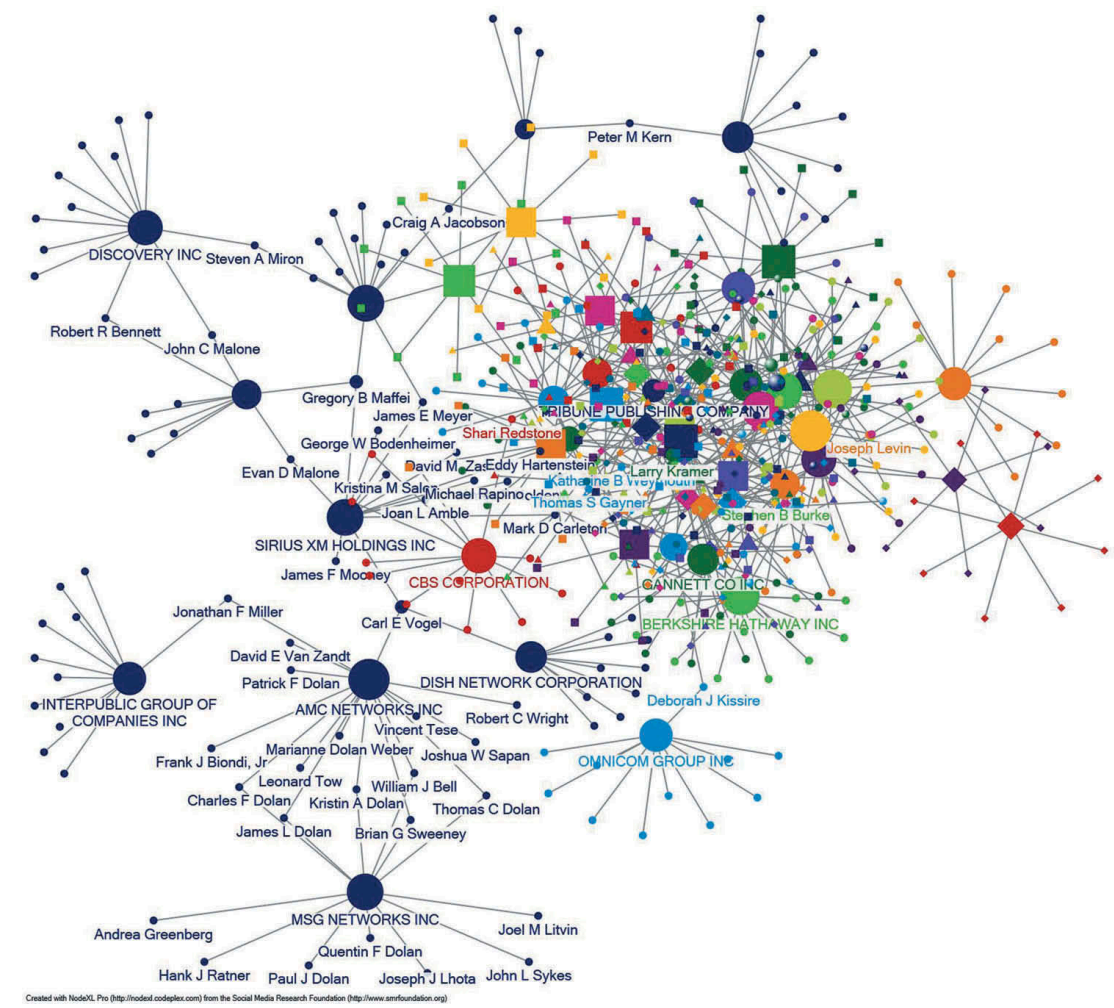

Figure 1. Organisation-to-individual social network of media conglomerates across seven sectors in the U.S., by eigenvector centrality. 


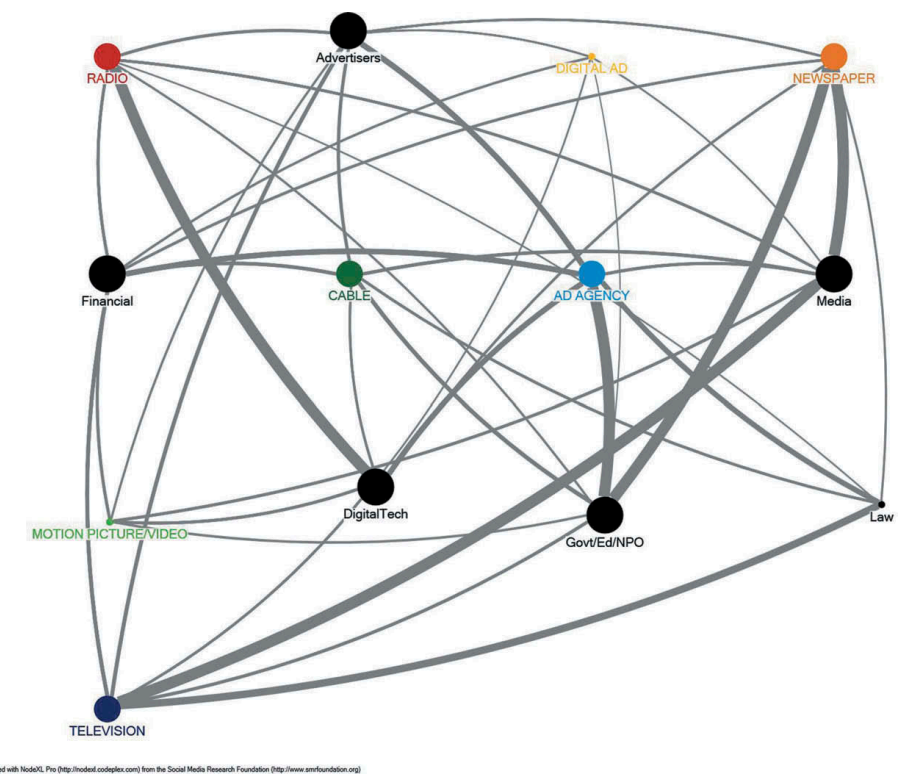

Figure 2. Media conglomerates' director compensation by resource categorisation across seven media sectors in the U.S.

And finally, director compensation is visualised as a sociogram to show the tie strength among the seven media sectors and six resource categories (see Figure 2). The wider the line between a media sector and a resource category, the higher the director compensation.

In sum, the interfirm interlocks of publicly traded U.S. media conglomerates across the seven media sectors were revealed in this research. The directors, alongside their compensation operationalised as the strength of a dyadic tie between the media conglomerate and its directors, and directors' most recent employer, depict the resources sought out by media conglomerates when forming organisational leadership structures. The centrality analyses and visualisation capabilities of the network perspective adds explanatory value to this investigation and allows a multilevel, multi-theoretical approach to such sociological phenomenon. Next, results are discussed through the lens of social resource theory to further explain the research questions and hypotheses.

\section{Discussion}

This research set out to identify seven media sectors' interfirm interlocks to investigate the resource-dependent alliance networks established among media organisations operating in the United States of America. Media conglomerates' interfirm interlocks were investigated by gathering each conglomerate's board of directors and examining each $U$. 
S. media sector's social network and desired resource categories, as evidenced by their directorship alliances. The application of the network perspective to this examination offered an in-depth explanatory overview of U.S. media conglomerates' interfirm interlock alliance networks and the resources exchanged among those networks. Further, the collection of compensation data delineated to which resource categories conglomerates are funnelling their funds as deemed necessary for continued business operations, oversight, and for resource exchange.

This study mirrored past research regarding media conglomerates (An \& Jin, 2005, 2004; Artero, 2009; Han, 1988; Picard, 1994; Simmons, 2012, 2011) by including newspaper publishers and other sectors of news-disseminating conglomerates like broadcast radio and television (Han, 1988; Simmons, 2012). A common theme among the findings of those past media-related studies was that advertisers were a critical resource category and therefore a common interfirm interlock. None, however, examined purposeful interlocking connections with advertising agencies, which largely control the placement of advertisements throughout all other media sectors. This study filled that gap.

This research indicates that the number of publicly traded media conglomerates across sectors are shrinking and fewer directors are serving. In the last decade, the number of publicly traded media conglomerates has shrunk from 73 in 2008 (Simmons, 2011) to 68 across all seven media sectors, and the number of directors have fallen - from 11.94 in the 1980s (Han, 1988) to 8.95 today. Recall here that this research extended the number of media sectors under review from those conducted in the past so today's number is considerably smaller than that of decades past. The fewer the number of directors, the more power each possess (Schoorman et al., 1981). These results should leave media producers and media consumers concerned for the future viability of some sectors of the information industry in the U.S.

Simmons (2012) found that media conglomerates that experienced the highest levels of environmental uncertainty recruited directors from financial institutions and advertisers. While financial interlocks are still the top resource category for each sector, financial interlocks are secondary to the overall media resource category, today. Also, the makeup of financial interlocks are very different today than in the past and technological change and resource dependency are having lasting effects on media interfirm interlocks. These matters are all discussed in more detail in the sections that follow, but first a discussion regarding the central role of advertising agencies across U.S. media sectors is presented.

\section{Advertising agencies hold a central position within U.S. media}

This research is the first to integrate publicly traded advertising agencies into an investigation of media conglomerate interfirm interlocks. Past studies have categorised advertisers only as a resource category and findings of each of those studies note statistical support for the connection between advertisers serving on boards of directors and financial health (An \& Jin, 2005, 2004; Han, 1988; Simmons, 2011). This research highlights that advertising agencies are both a media sector and a resource category within the U.S. media ecosystem. As a result, and in support of the second hypothesis, numerous publicly-traded advertising conglomerates were central to the overall U.S. media industry network.

In fact, four advertising conglomerates were among the top 20 most central media conglomerates in the whole network: the Interpublic Group of Companies Inc, MDC Partners Inc, Omnicom Group, and Roper Technologies Inc. The Interpublic Group of 
Companies Inc, the parent company of McCann and 94 other advertising and public relations agencies, is interlocked with AMC Networks Inc, and by relation to MSG Networks and Altice USA Inc (Cablevision). Omnicom, the parent to over 1,500 agencies, also is central in the network, is connected to Graham Holdings Company through its directorship interlock with Cable One. Larry Kramer serves on three boards, thus interlocking the three: Gannett, TheStreet, and MDC Partners Inc. MDC Partners is an advertising and marketing holding company partnered with over 50 agencies. See Figure 1 for a visualisation of these and other connections.

An and Jin (2005) reported that advertiser interlocks reduces operational uncertainty and secures capital (p. 22). The authors go so far as to assert that "ties to leading advertisers increased corporate financial performance, while ties to financial institutions did not” (p. 23). A modern-day example of what An and Jin described is the relationship between The Walt Disney Company and General Motors (GM). Marry Bara, GM's CEO, serves on Disney's board of directors. GM enjoys ongoing product-placement deals with Disney. For example, GM's Chevrolet line are the featured vehicles in "Captain America: The Winter Soldier" (McCarthy, 2014). This partnership demonstrates a mutual benefit in that GM may pay less in advertising dollars while Disney reduces operational uncertainty and secures capital (An \& Jin, 2005). The Disney-GM alliance are the very type of alliances that can reduce operational uncertainty, secure capital, and "increase corporate financial performance" for media companies (An \& Jin, 2005, pp. 22-23), and more conglomerates should follow suit.

\section{Alliance networks for technological change}

This research hypothesised that media conglomerates have adapted to the technological change brought on by the turn of the century's mass emergence of technological advancement with the spread of the internet. The hypothesis that technological change would be reflected among interlocked directorships with digital or technological organisations was supported across all seven sectors. Tatarynowicz et al. (2016) asserted that organisations can expand their network by embracing technological change through increased collaborative efforts by pursuing "more diverse resources and knowledge [for] critical inputs to innovation" (p. 54).

Media conglomerates appear to be embracing this strategy, albeit slowly. For example, the newest board member for the newly-merged Gannett/New Media conglomerate is Mayur Gupta, a digital marketing expert. Today's media conglomerates are interlocking with cutting-edge technological advances including one virtual reality firm, four artificial intelligence firms, one bitcoin firm, and two cybersecurity firms. Interlocks that match environmental needs perform better (Zona et al., 2018), and interlocks that address technological change are the perfect example of how strategic alliances form to aid organisations with resource exchange (An \& Jin, 2005; Simmons, 2012).

Still though, the number of technology and adverting interlocks were not as prevalent as media scholars might hypothesise given some media sectors' level of environmental uncertainty or need for consistent technological change to remain competitive. In fact, economic instability remains a top concern for some sectors, as is demonstrated by the number and type of financial interlocks found in this investigation. The next section reviews the industry's financial interlocks and discusses how these types of interlocks can lead to cooptation. 


\section{Financial interlocks among U.S. media conglomerates}

What's been missing from past research regarding interfirm interlocks and resource dependency, and what serves as food for thought for media economists, is a specific focus on the types of financial interlocks U.S. media conglomerates have initiated. This section discusses how these specific and functional alliances have changed in recent decades and why conglomerates should take heed of their effects.

Financial interlocks held the highest prevalence among directorships in every sector except the motion pictures sector. These financial interlocks ranged from $20 \%$ to $36 \%$ of each media sector's board makeup, and is the most compensated resource category. The vast majority of financial interlocks were with directors connected with investors, hedge funds, venture capitalists, and private equity firms. Few traditional banking institutions were interlocked across all seven media sectors, a stark difference from Han's (1988) study.

In a general sense, financial interlocks have been hypothesised as offering access to the necessary resources for operational benefit and for expertise regarding financial matters (An \& Jin, 2005; Han, 1988), but what has become evident, especially within the newspaper sector, is that financial interlocks are having long-lasting negative effects on the reshaping of directorships, even inciting directorship wars. Cooptation (i.e. surrendering some autonomy in return for resources) is becoming more recognisable as majority shareholders are mandating placement of preferred directors due to majority stock agreements in these resource-dependent interlocks. This current research found that exactly half of all financial interlocks across all seven media sectors were with investment, equity, and venture capital firms, and only six interlocks existed with banks or credit institutions. The current makeup of financial interlocks looks very different from the snapshot captured by An and Jin (2005, see p. 19) regarding the newspaper sector at that time. One must ask, once the boards of directors are under majority financial control with venture capital investors, what will happen to the U.S. information industry?

Financial interlocks possess an inherent potential for influence over an organisation (Picard, 1994). Moreover, financial interlocks oftentimes hold the most powerful positions. Take, for example, the 2019 merger between Gannett and New Media Investment Group. The merger was negotiated with each organisation's CEO and board chairman as the lead negotiators. John Jeffry Louis was Gannett's board chairman and is co-founder of Parson Capital Corporation, a venture capital firm. Wes Edens has served as New Media's board chairman since its inception when the organisation was structured to consume Gatehouse Media Inc after bankruptcy. Edens also is co-CEO of Fortress Investment Group LLC, a global investment management firm. Fortress, according to media reports (Kirchen, 2019) and the SEC filings regarding the merger, is at the forefront of the restructuring for the newly-merged mammoth media organisation. Edens now provides oversight to what is arguably the largest U.S. newspaper conglomerate in history. Edens and Fortress additionally have financial business ties to the Trump International Hotel and Tower in Chicago (Sheth, 2019), is co-owner of the Milwaukee Bucks, and an investor in the Bucks' new Fiserv Forum arena where the 2020 Democratic National Convention will take place (Murphy, 2019). 


\section{Social resource theory and U.S. media interfirm interlocks}

The application of social resource theory aided in this examination of the architecture and flow of today's interfirm interlocks across seven sectors of U.S. media via the lens of dependency and exchange network assumptions (Borgatti \& Lopez-Kidwell, 2011; Lin, 2017; Monge \& Contractor, 2003). Social resource theory guided this research by focusing on the network structures of the media conglomerates' interlocks to explore the similarities, social relations, and interactions among the interlocked organisations and individuals (Borgatti \& Lopez-Kidwell, 2011; Himelboim, Golan, Moon, \& Suto, 2014). Recall here that a network's architecture reveals a node's position and its dependency on, or ability to reach, other nodes to exchange resources throughout the network. A node's network position helps a researcher decipher whether a node is resource-rich or resource-poor or whether a partnership is a horizontal partnership or a vertical hierarchy (Borgatti \& Lopez-Kidwell, 2011). Taken together, social resource theory explains that interlocks such as the one between MDC Partners and Gannett is strategic, functional, and mutually beneficial because both conglomerates' income is at least partially reliant on advertising sales. MDC Partners services advertisers and therefore has ties to social and economic connections that would benefit Gannett economically. MDC Partners have a higher degree centrality than Gannett within the network, therefore, making MDC Partners vertically superior to Gannett.

Mizruchi (1996) once noted traditional "interlock analyses fail to capture the richness and complexity of board dynamics and interfirm relations” (p. 292). The current research supports that assertation and extends prior literature with the inclusion of relationship intensity. For example, this social network analysis assessed centrality measurements, network reach, and applied functional specificity (Perry \& Pescosolido, 2010; Weiss, 1974; Wellman \& Wortley, 1990) to investigate alliances (Beckman et al., 2004) among interfirm interlocks for mutual benefit, and this research ultimately revealed that the business of U.S. media is a family affair.

Media conglomerates possess kinship ties among directorships, executives, and other conglomerates and interfirm interlocks. The eigenvector centrality measurements in the organisation-to-individual social network depicts these phenomena and the implications of these familial ties regarding resource exchange and dependency. The Dolan family, for example, are tied to several conglomerates, including AMC Networks Inc and MSG Networks Inc. The proxy reports for these organisations include disclaimers regarding the sharing of costs for office space for Charles Dolan and other family members and reflects preferential spending among the interlocked family's businesses, therefore securing capital by accessing resources more freely than non-family members. Several other instances of familial ties reflect conglomerate consumption of competitor media organisations. For example, News Corporation acquired Dow Jones, which was owned by Bancroft family, and Natalie Bancroft serves on the News Corporation board. Other conglomerates with familial interlocks include: Beasley Broadcast Group, Cox, E.W. Scripps, Graham Holdings Company (formerly Washington Post), New York Times Co, Salem Media Group Inc, Sinclair Broadcast Group, and Spanish Broadcasting. Salem Media Group Inc also mentioned in its proxy report that several directors are customers. 


\section{Practical implications and conclusion}

The practical implications of this research include three main recommendations for media conglomerates: (1) a thorough review of current directors alongside an assessment of resource dependency to create mutually beneficial strategic alliances; (2) to ease up on media directors, familial ties, and the number of internal directors to diversify access to resources; and (3) to conduct threat assessments regarding financial interlocks. To explain, directors serve for specified terms (some longer, some shorter than others) and then as the term nears its end, the director goes up for re-election with no service cap on how many total years a director can serve. Conglomerates in this study had directors who have served for decades. Perhaps U.S. media conglomerates should review these relationships and assess whether those directors are still specific, functional strategic alliances for mutual benefit and resource exchange (Perry \& Pescosolido, 2010; Weiss, 1974; Wellman \& Wortley, 1990).

Furthermore, $40 \%$ of directorships across all seven media sectors were made up of the resource category of media, which includes their own executives. Interfirm interlocks must diversify their directorships to gain access to more resources. In network theory, these ties are considered redundant and limiting to information or resource exchange (Borgatti \& Lopez-Kidwell, 2011). While these conglomerates do need some industry-specific governance and expertise, diversifying resource categories among directorships would garner more favourable bottom-line results. Also, some financial connections can possess larger, more macro repercussions. The vast difference in the makeup of financial ties today from before the turn of the century depicts a staggering turn to venture capitalists and independent financiers, instead of banking institutions. As recently witnessed with the Gannett-New Media merger, and Fortress' role within that merger (Kirchen, 2019), financial ties should be closely monitored and diversified in an effort to spread resource exchange, reduce resource dependency with any one financier, and thus provide protections against such power differentials regarding cooptation.

As with any social science investigation, limitations exist. This study is based upon publicly available information gathered and verified across online governmental and educational databases. It is possible that each conglomerate's list of directors could omit individuals or not include recent departures. Although every attempt was made to verify such facts with reputable sources, no true census can ever fully be achieved. Still though, this dataset offers enough of a sample of the fiscal year 2018 social network of media conglomerates operating in the U.S. to generalise the discussion offered above and the recommendations that followed. Also, this research was not longitudinal like other interlocking research of the past (Mizruchi \& Stearns, 1988; Palmer et al., 1986; Zajac \& Westphal, 1996), including those focused on U.S. media (An \& Jin, 2005, 2004; Simmons, 2012), but instead is a snapshot of one point in time. As such, a limitation to this work is that the data period includes the most recently reported year only (2018), so the number of directors serving on more than one media board simultaneously $(\mathrm{n}=28)$ is not a historical reflection of industry norms.

Future research might examine the economic impact of interlocks to assess the financial health of U. S. media conglomerates. Moreover, Simmons (2012) asserted that conglomerates were not interlocking "to deal with industry-level media consolidation" (p. 69). The current research suggests otherwise, so this also would be an interesting future research approach.

In conclusion, this research set out to examine today's interfirm interlocks among publicly traded U.S. media conglomerates across seven media sectors. The network perspective added explanatory value into this investigation through the application of social resource theory, 
functional specificity, and the assessment of resource exchange and dependency. Results indicate that interfirm interlocks among U.S. media conglomerates demonstrate resource exchange but some sectors (e.g. the newspaper sector) have fallen victim to cooptation. Financial interlocks have evolved from banking institutions in the 1980s to venture capitalist and investment firms in the 2010s, thus forming dependent interlocks that are continually reshaping directorships, inciting directorship wars, and collapsing some sectors. The unique inclusion of the advertising sector in this research highlights the strategic and beneficial alliance opportunities available to U.S. media to secure capital and reduce environmental uncertainty. Moreover, the advertising sector was central and well-connected to the overall U.S. media network because of its unique ability to double as a resource category. Technological adaption also was evidenced in this investigation and the most recent interfirm interlocks reveal resource exchange with an array of digital and technological firms. Still though, media directorships could improve strategic alliances if each conglomerate diversifies its board with fewer media and familial interlocks for broader resource exchange. Overall, this research identified the current social resources available through the interlocks of publicly traded U.S. media conglomerates' directorships across seven media sectors and the results of this research suggest where the strengths and weaknesses exist in today's U.S. media ecosystem.

\section{Notes}

1. The NAICS Information sector brings together those activities that transform information into a commodity that is produced and distributed, and activities that provide the means for distributing those products. Industries included in this sector are telecommunications; broadcasting; newspaper, book, and periodical publishing; motion picture and sound recording industries; libraries; and other information services (Census.gov).

2. The data that support the findings of this study are available from the corresponding author, [JLH], upon request.

\section{Disclosure statement}

No potential conflict of interest was reported by the author.

\section{Notes on contributor}

Jennifer L. Harker (Ph.D., The University of North Carolina at Chapel Hill) is an assistant professor of strategic communication in the Reed College of Media at West Virginia University. Dr. Harker applies the network perspective to her research in the areas of media business models, sport communication, and stakeholder perceptions.

\section{ORCID}

Jennifer L. Harker (D) http://orcid.org/0000-0002-0483-5465

\section{References}

An, S., \& Jin, H. S. (2005). The effects of interlocking directorates on the financial performance of publicly traded newspaper companies: A longitudinal approach. In R. G. Picard (Ed.), Corporate 
governance of media companies (pp. 11-28). Jönköping, Sweden: Jönköping International Business School. Retrieved from http://center.hj.se/download/18.2eec38e0133eaaf ba4a80002985/book_corporate_governance.pdf\#page $=17$

An, S., \& Jin, H. S. (2004). Interlocking of newspaper companies with financial institutions and leading advertisers. Journalism \& Mass Communication Quarterly, 81(3), 578-600.

Artero, J. P. (2009). Corporate governance and risk identification in global media companies. Media Markets Monographs Series, No. 10. Servicio de Publicaciones de la Universidad de Navarra.

Beckman, C. M, Haunschild, P. R, \& Phillips, D. J. (2004). Friends or strangers? firm-specific uncertainty, market uncertainty, and network partner selection. Organization Science, 15(3), 259-275. doi: $10.1287 /$ orsc. 1040.0065

Beckman, C. M., Haunschild, P. R., \& Phillips, D. J. (2004). Friends or strangers? Firm-specific uncertainty, market uncertainty, and network partner selection. Organization Science, 15(3), $259-275$.

Borgatti, S. P., \& Lopez-Kidwell, V. (2011). Network theory. In J. Scott \& P. J. Carrington (Eds.), The SAGE handbook of social network analysis (pp. 40-54). Thousand Oaks, CA: Sage doi:10.4135/9781446294413

Borgatti, S. P., Everett, M. G., \& Johnson, J. C. (2013). Analyzing social networks. Thousand Oaks, CA: Sage Publications Limited.

Borgatti, S. P., Jones, C., \& Everett, M. G. (1998). Network measures of social capital. Connections, 21(2), 27-36.

Bourdieu, P. (1985). The social space and the genesis of groups. International Social Science Council, 24(2), 195-220.

Burt, R. S. (2004). Structural holes and good ideas. American Journal of Sociology, 110(2), 349-399.

Coleman, J. S. (1988). Social capital in the creation of human capital. American Journal of Sociology, 94, 95-120.

Colistra, R. (2012). Shaping and cutting the media agenda: Television reporters' perceptions of agenda-and frame-building and agenda-cutting influences. Journalism \& Communication Monographs, 14(2), 85-146.

Colistra, R. (2018). Power pressures and pocketbook concerns: Perceptions of organizational influences on news content in the television industry. International Journal of Communication, 12, 21.

Galaskiewicz, J., Wasserman, S., Rauschenbach, B., Bielefeld, W., \& Mullaney, P. (1985). The influence of corporate power, social status, and market position on corporate interlocks in a regional network. Social Forces, 64(2), 403-431.

Gannett Investor Relations. (2019, April 27). Gannett sends open letter to shareholders. Business Wire. Online. Retrieved from https://investors.gannett.com/press-release/gannett-sends-openletter-shareholders

Granovetter, M. S. (1973). The strength of weak ties. American Journal of Sociology, 78(6), 13601380.

Han, K. T. (1988). Composition of board of directors of major media corporations. Journal of Media Economics, 1(2), 85-100.

Himelboim, I., Golan, G. J., Moon, B. B., \& Suto, R. J. (2014). A social networks approach to public relations on Twitter: Social mediators and mediated public relations. Journal of Public Relations Research, 26(4), 359-379.

iHeartMedia. (2018, November 6). iHeartMedia announces post-emergence board of directors. Retrieved from https://www.iheartmedia.com/press/iheartmedia-announces-post-emergenceboard-directors

Kirchen, R. (2019, Sept. 4). Wes Edens led New Media's initial acquisition talks with Journal Sentinel owner Gannett. Milwaukee Business Journal, online. Retrieved from https://www bizjournals.com/milwaukee/news/2019/09/03/wes-edens-led-new-medias-initial-acquisitiontalks.html

Koenig, T., \& Gogel, R. (1981). Interlocking corporate directorships as a social network. American Journal of Economics and Sociology, 40(1), 37-50. 
Lamb, N. H., \& Roundy, P. (2016). The "ties that bind" board interlocks research: A systematic review. Management Research Review, 39(11), 1516-1542.

Lang, J. R., \& Lockhart, D. E. (1990). Increased environmental uncertainty and changes in board linkage patterns. Academy of Management Journal, 33(1), 106-128.

Lin, N. (1999a). Building a network theory of social capital. Connections, 22(1), 28-51.

Lin, N. (1999b). Social networks and status attainment. Annual Review of Sociology, 25(1), 467487.

Lin, N. (2017). Building a network theory of social capital. In Social capital (pp. 3-28). Routledge. doi:10.4324/9781315129457-1.

Logan, R. K. (2007). The biological foundation of media ecology. Explorations in Media Ecology, 6 (1), 19-34

McCarthy, M. (2014, April 5). New Corvette gets driven by Scarlett Johansson in "Captain America". Automotive News. Online. Available at https://www.autonews.com/article/20140405/RETAIL03/ 140409882/new-corvette-gets-driven-by-scarlett-johansson-in-captain-america

MDC Partners Inc. (2019, April 22). Kristen O'Hara and additional new independent director to be added to company slate of 2019 nominees. PRNewswire. Online. Retrieved from https://www. prnewswire.com/news-releases/mdc-partners-announces-board-updates-mdc-reaches-agree ment-with-frontfour-capital-300835887.html

Mirer, M., \& Harker, J. (2019). Will the crowd go wild?: Reimagining the newspaper sports section for digital subscribers. Journalism Practice, 1-17. doi:10.1080/17512786.2019.1697955

Mizruchi, M. S. (1996). What do interlocks do? An analysis, critique, and assessment of research on interlocking directorates. Annual Review of Sociology, 22(1), 271-298.

Mizruchi, M. S., \& Stearns, L. B. (1988). A longitudinal study of the formation of interlocking directorates. Administrative Science Quarterly, 33(2), 194-210.

MNG Enterprises, Inc. (2019, April 26). MNG outlines simple case for change at Gannett board. Business Wire. Online. Retrieved from https://www.businesswire.com/news/home/ 20190426005516/en/MNG-Outlines-Simple-Case-Change-Gannett-Board.

Monge, P. R., \& Contractor, N. S. (2003). Theories of communication networks. New York, NY: Oxford University Press.

Murphy, B. (2019, April 16). Taxpayers make bucks, Brewers rich. Urban Milwaukee, online. Retrieved from https://urbanmilwaukee.com/2019/04/16/murphys-law-taxpayers-make-bucks-brewers-rich/

Nahapiet, J., \& Ghoshal, S. (1998). Social capital, intellectual capital, and the organizational advantage. Academy of Management Review, 23(2), 242-266.

Neuman, W. R. (2010). Media, technology, and society: Theories of media evolution. University of Michigan Press. doi:10.3998/dcbooks.8232214.0001.001

O'Connell, J. (2019, May 16). Gannett shareholders reject hedge fund's board candidates. Washington Post. Online. Available at https:/www.washingtonpost.com/business/2019/05/16/ gannett-shareholders-reject-hedge-funds-board-candidates/?utm_term=.9b101a82e $37 \mathrm{f}$.

Opsahl, T., Agneessens, F., \& Skvoretz, J. (2010). Node centrality in weighted networks: Generalizing degree and shortest paths. Social Networks, 32(3), 245-251.

Palmer, D., Friedland, R., \& Singh, J. V. (1986). The ties that bind: Organizational and class bases of stability in a corporate interlock network. American Sociological Review, 51(6), 781-796.

Perry, B., Pescosolido, B., \& Borgatti, S. (2018). Egocentric network analysis: Foundations, methods, and models (Structural analysis in the social sciences). Cambridge: Cambridge University Press. doi:10.1017/9781316443255

Perry, B. L., \& Pescosolido, B. A. (2010). Functional specificity in discussion networks: The influence of general and problem-specific networks on health outcomes. Social Networks, 32 (4), 345-357.

Pfeffer, J., \& Salancik, G. R. (2003). The external control of organizations: A resource dependence perspective. Stanford, CA: Stanford University Press.

Picard, R. G. (1994). Institutional ownership of publicly traded US newspaper companies. Journal of Media Economics, 7(4), 49-64.

Picard, R. G. (2003). The economics of the daily newspaper industry. In Media Economics (pp. 119-136). Routledge. 
Picard, R. G. (2005a). Corporate governance: Issues and challenges. In R. G. Picard (Ed.), Corporate governance of media companies (pp. 1-20). Jönköping, Sweden: Jönköping International Business School. Retrieved from http://center.hj.se/download/18.2eec38e0133eaaf ba4a80002985/book_corporate_governance.pdf\#page=1

Picard, R. G. (2005b). Unique characteristics and business dynamics of media products. Journal of Media Business Studies, 2(2), 61-69.

Picard, R. G. (2006). Historical trends and patterns in media economics. In In Albarran, A. B., Chan-Olmsted, S. M., \& Wirth, M. O. (Eds.), Handbook of Media Management and Economics (pp. 35-48). London: Lawrence Erlbaum.

Schoorman, F. D., Bazerman, M. H., \& Atkin, R. S. (1981). Interlocking directorates: A strategy for reducing environmental uncertainty. Academy of Management Review, 6(2), 243-251.

Scolari, C. A. (2013). Media evolution: Emergence, dominance, survival and extinction in the media ecology. International Journal of Communication, 7, 24.

Scott, J. (1988). Social network analysis. Sociology, 22(1), 109-127.

Sheth, S. (2019, September 6). Trump may have committed tax fraud by fabricating a loan to avoid paying income taxes on nearly $\$ 50$ million. Business Insider, online. Retrieved from https:// www.businessinsider.com/trump-may-have-made-up-loan-tax-fraud-mother-jones-2019-9

Simmons, C. N. (2011). Converging competitors? Board interlocks in the changing media landscape. Journal of Media Economics, 24(3), 201-213.

Simmons, C. N. (2012). Will you be on our board of directors? We need help: Media corporations, environmental change, and resource dependency theory. Journalism \& Mass Communication Quarterly, 89(1), 55-72.

Smith, M., Ceni, A., Milic-Frayling, N., Shneiderman, B., Mendes Rodrigues, E., Leskovec, J., \& Dunne, C. (2010). NodeXL: A free and open network overview, discovery and exploration addin for Excel 2007/2010/2013/2016. Social Media Research Foundation. Retrieved from https:// www.smrfoundation.org

Stelter, B. (2019, March 19). Former Speaker of the House Paul Ryan joins board of Fox Corporation. CNN Business. Online. Retrieved from https://www.cnn.com/2019/03/19/media/ paul-ryan-fox-corporation/index.html

Tatarynowicz, A., Sytch, M., \& Gulati, R. (2016). Environmental demands and the emergence of social structure: Technological dynamism and interorganizational network forms. Administrative Science Quarterly, 61(1), 52-86.

Thomas, P. (2019, April 22). MDC to add new directors in settlement with activist investor. Wall Street Journal. Online. Retrieved from https://www.wsj.com/articles/mdc-to-add-new-direc tors-in-settlement-with-activist-investor-11555974762

United States Census Bureau (2017). North American industry classification system. Retrieved from https://www.census.gov/eos/www/naics/

Walker, G., Kogut, B., \& Shan, W. (1997). Social capital, structural holes and the formation of an industry network. Organization Science, 8(2), 109-125.

Weiss, R. S. (1974). The provisions of social relationships. In Z. Rubin (Ed.), Doing unto others (pp. 17-26). Englewood Cliffs, NJ: Prentice-Hall.

Wellman, B., \& Wortley, S. (1990). Different strokes from different folks: Community ties and social support. American Journal of Sociology, 96(3), 558-588.

Wry, T., Cobb, J. A., \& Aldrich, H. E. (2013). More than a metaphor: Assessing the historical legacy of resource dependence and its contemporary promise as a theory of environmental complexity. The Academy of Management Annals, 7(1), 441-488.

Xia, J., Wang, Y., Lin, Y., Yang, H., \& Li, S. (2018). Alliance formation in the midst of market and network: Insights from resource dependence and network perspectives. Journal of Management 44(5), 1899-1925.

Zajac, E. J., \& Westphal, J. D. (1996). Director reputation, CEO/board power, and the dynamics of board interlocks. Academy of Management Proceedings, 1996(1), 254-258.

Zona, F., Gomez-Mejia, L. R., \& Withers, M. C. (2018). Board interlocks and firm performance: Toward a combined agency-resource dependence perspective. Journal of Management, 44(2), 589-618. 